\title{
COVID-19 lockdown NOx emission reductions can explain most of the coincident increase in global atmospheric methane
}

\author{
David S. Stevenson ${ }^{1}$, Richard G. Derwent ${ }^{2}$, Oliver Wild ${ }^{3}$, William J. Collins ${ }^{4}$ \\ ${ }^{1}$ School of GeoSciences, The University of Edinburgh, Edinburgh EH9 3FF, UK \\ $5 \quad{ }^{2}$ rdscientific, Newbury, UK \\ ${ }^{3}$ Lancaster Environment Centre, Lancaster University, Lancaster, UK \\ ${ }^{4}$ Department of Meteorology, University of Reading, Reading, UK
}

Correspondence to: David S. Stevenson (David.S.Stevenson@ed.ac.uk)

Abstract. Compared to 2019, the global growth rate of atmospheric methane rose by about 50\% in 2020, reaching $15 \mathrm{ppb} / \mathrm{yr}$.

Models of global atmospheric chemistry show that reductions in nitrogen oxide (NOx) emissions reduce levels of the hydroxyl radical, and lengthen the methane lifetime. Using estimates of NOx emission reductions associated with COVID-19 lockdowns around the world in 2020, together with model-derived regional and sectoral sensitivities of methane to NOx emissions, we find that NOx emissions reductions can fully explain the observed surge in the global methane growth rate. Whilst changes in NOx emissions are probably not the only important factor that has influenced methane since the beginning of 2020, it is clear

15 that they are a key factor that will need to be included within any attribution study, and that they may well be the dominant driver of these recent methane changes. The major global scale changes in composition of the Earth's atmosphere measured during lockdown provide unprecedented constraints on the sensitivity of the atmospheric chemical system to changes in emissions, and are of great utility for evaluating policy-relevant models.

\section{Introduction}

20 Methane is a powerful greenhouse gas and important precursor of tropospheric ozone; both are key air pollutants and shortlived climate forcers (SLCFs). The 2013 Intergovernmental Panel on Climate Change assessment estimated methane's Global Warming Potential (GWP) over a 100 year time horizon to be 28 (Myhre et al., 2013); updates to its short-wave radiative forcing have increased this value by $14 \%$ (Etminan et al., 2016). Advances in our understanding of how GWP metrics relate to climate change indicate that it is not only the magnitude of emissions, but also the rates of change of SLCFs like methane that strongly influence near-term global temperature changes (Allen et al., 2018; Cain et al., 2019). These post-2013 updates increase the importance of methane and its evolution in the context of the Paris Climate Agreement target that seeks to limit warming to $1.5^{\circ} \mathrm{C}$ above pre-industrial levels.

Following the onset of the COVID-19 pandemic in early 2020, the trace gas composition of the global atmosphere has shown substantial changes. Atmospheric nitrogen oxide (NOx) levels have reduced, whilst the measured growth rate of methane $\left(\mathrm{CH}_{4}\right)$ has risen sharply. The observed NOx changes are clearly linked to falls in emissions resulting from lockdowns, but the 
methane increases remain unexplained (e.g., Vaughan, 2021). Methane and NOx are linked through the oxidising capacity of the atmosphere, specifically by the abundance of the hydroxyl $(\mathrm{OH})$ radical. The response of global atmospheric chemistry to the large lockdown perturbation since early 2020 provides an opportunity to explore the sensitivity of the NOx-OH-CH system, and compare models and observations. Here we use model-derived sensitivities of methane to NOx, together with estimated changes in anthropogenic NOx emissions related to the COVID-19 lockdowns, to calculate the impacts on the growth rate of global methane, and compare this to methane observations.

\section{Measurements of atmospheric methane and nitrogen oxides}

Recent methane measurements from the US National Oceanographic and Atmospheric Administration (NOAA) show that the atmospheric methane growth rate rose sharply from $9.9 \mathrm{ppb} / \mathrm{yr}$ in 2019 to $14.8 \mathrm{ppb} / \mathrm{yr}$ in 2020, the highest annual value in the

40 37-year NOAA record (Figure 1; Dlugokencky, 2021). Many of the earlier large year-to-year jumps in methane's growth rate relate in part to variability in climate and emissions associated with El Niño Southern Oscillation (ENSO), and in particular because of modulation of methane's main sink, oxidation by OH (Turner et al., 2018; Zhao et al., 2020). ENSO indices have not shown strong variations over 2019-2020 (WMO, 2021).

Measurements of nitrogen dioxide $\left(\mathrm{NO}_{2}\right)$ from satellite instruments and nitrogen monoxide (NO) and $\mathrm{NO}_{2}$ from surface sites

45 show that levels of atmospheric $\mathrm{NOx}\left(\mathrm{NO}+\mathrm{NO}_{2}\right)$ dramatically fell globally during 2020 (Bauwens et al., 2020) as COVID19 lockdowns around the world reduced emissions, mainly from transportation (Venter et al., 2020; Lamboll et al., 2021).

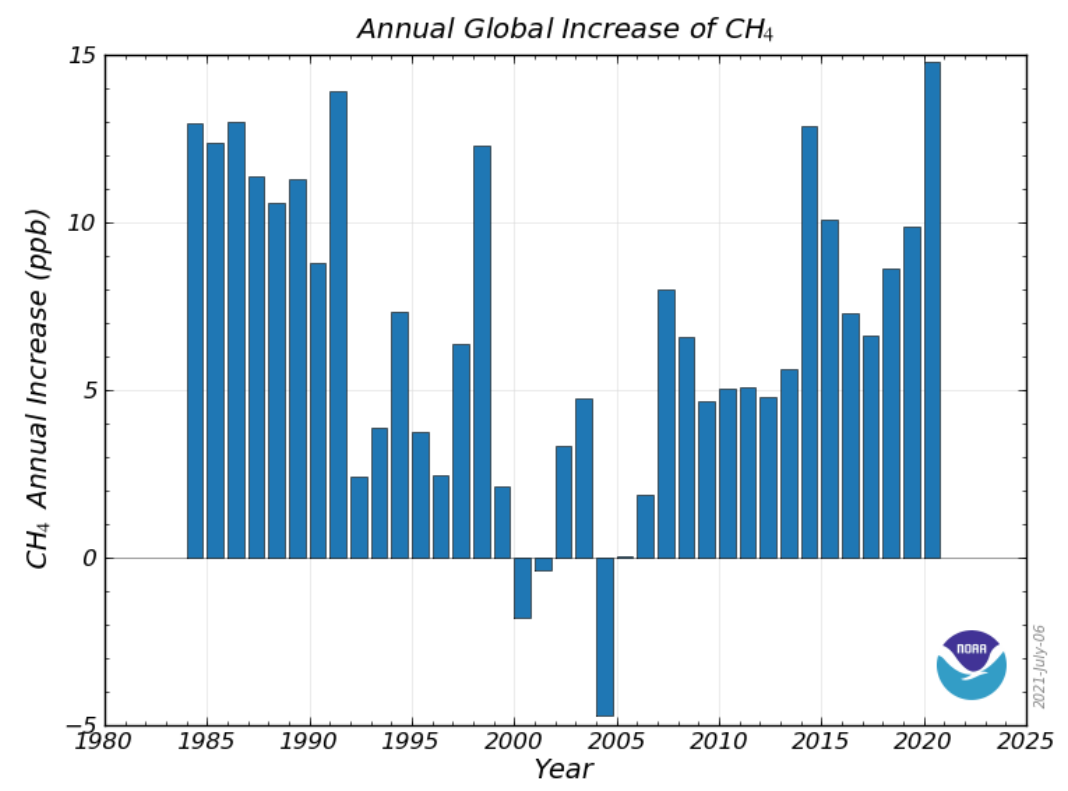

Figure 1: Global annual changes in surface atmospheric methane mole fraction (ppb) 1984-2020 (Dlugokencky, 2021). 


\section{Sensitivity of global methane to NOx emissions}

Global atmospheric chemistry model simulations indicate that decreases in NOx emissions lead to reductions in $\mathrm{OH}$ and increases in the methane lifetime (Prather, 1994; Derwent et al., 2001; Wild et al., 2001; Stevenson et al., 2004; Weber et al., 2020). Multi-model studies have calculated methane effects for NOx emissions from specific world regions (Fry et al., 2012) and the aviation sector (Lee et al., 2021). Although methane has an atmospheric lifetime of about 10 years, the models show that its peak response occurs within a few months of the cessation of a sudden short-lived (month- or year-long) pulse of extra NOx emissions (Derwent et al., 2001; Wild et al., 2001; Stevenson et al., 2004).

Derwent et al. (2001) conducted a series of experiments with the global tropospheric chemistry model STOCHEM to quantify the impact of NOx emissions on methane. They compared a 4-year long base simulation with a perturbation simulation that was identical apart from an enhancement in NOx emissions of magnitude $1 \operatorname{Tg}\left(\mathrm{NO}_{2}\right)$, added during the first month with the Northern Hemisphere surface anthropogenic NOx emissions distribution. The extra NOx produced a short-lived increase in $\mathrm{OH}$, and this led to a rapid depletion of global methane, which peaked at around $0.39 \mathrm{Tg}\left(\mathrm{CH}_{4}\right)$ after about six months. The methane deficit then exponentially decayed with an e-folding timescale of about 12 years (the methane perturbation lifetime), with methane levels returning towards their base values. Wild et al. (2001) conducted similar experiments, with year-long perturbations using a different model (UCI CTM), and found slightly larger sensitivities: $1 \operatorname{Tg}\left(\mathrm{NO}_{2}\right)$ from global fossil fuel sources yielded a $0.55 \mathrm{Tg}$ depletion of $\mathrm{CH}_{4}$. Fry et al. (2012) analysed multi-model experiments from the Hemispheric Transport of Air Pollutants (HTAP) study that isolated the impacts on methane of surface NOx emissions from Europe, North America, and South and East Asia. For each region, Fry et al. (2012) compared a base simulation to one with $20 \%$ lower anthropogenic NOx emissions from that region. These simulations had methane fixed as a prescribed boundary condition, but diagnosed the change in methane lifetime associated with changes in $\mathrm{OH}$. From these changes in methane lifetime, the equilibrium change in methane was calculated, that is the change in methane that would have been achieved if methane levels had been free to respond (e.g., see Stevenson et al., 2013). In model simulations with methane not prescribed, it adjusts towards equilibrium with an e-folding time given by the methane perturbation lifetime ( $\tau$ ) (Holmes, 2018). To convert equilibrium methane changes derived from sustained changes in emissions to the equivalent response for a pulse of emissions, we use the perturbation lifetime to calculate the fraction of the equilibrium response that would have been reached after one year; for a methane perturbation lifetime of 12.4 years (Holmes, 2018) this fraction is $\left(1-\mathrm{e}^{-1 / \tau}\right)=7.7 \%$.

Similar model simulations have calculated the sensitivity of methane to aviation NOx emissions. Wild et al. (2001) and Stevenson et al. (2004) conducted pulse experiments adding NOx using the global aviation NOx emissions distribution, and found a peak impact on methane of about 2.5-2.6 Tg for a $1 \mathrm{Tg}\left(\mathrm{NO}_{2}\right)$ emission perturbation. Lee et al. (2021) assessed multi-

80 model results for aviation NOx emissions using sustained changes, which we convert, as described above, to the equivalent response for a pulse of emissions, and find a similar sensitivity. 
Table 1 summarises results from all these existing studies. For surface NOx emissions reductions of $1 \mathrm{Tg}\left(\mathrm{NO}_{2}\right)$ over one year, models find peak increases in global methane burden of about $0.5 \mathrm{Tg}$, with about five times higher sensitivities for reductions in aviation NOx. There is significant variation in sensitivity between regions for surface NOx emissions, with South Asia about twice as sensitive as North America and East Asia, and three times as sensitive as Europe (Fry et al., 2012). Stevenson and Derwent (2009) also found spatial variation in sensitivity for aviation NOx, with the more sensitive regions tending to have lower background NOx levels.

\begin{tabular}{|c|c|c|c|}
\hline $\begin{array}{l}\text { NOx emission } \\
\text { region/sector }\end{array}$ & $\begin{array}{c}\Delta C H_{4} / \Delta E_{N O x} \\
\operatorname{Tg}\left(C_{4}\right) / \operatorname{Tg}\left(\mathrm{NO}_{2}\right) \mathrm{yr}^{-1}\end{array}$ & $\begin{array}{c}2020-2019 \Delta \mathrm{E}_{\mathrm{NOx}} \\
\operatorname{Tg}\left(\mathrm{NO}_{2}\right) \mathrm{yr}^{-1}\end{array}$ & $\begin{array}{c}\Delta \mathrm{CH}_{4} \\
\operatorname{Tg}\left(\mathrm{CH}_{4}\right)\end{array}$ \\
\hline \multicolumn{4}{|l|}{ Surface emissions } \\
\hline Global & $-0.55^{\mathrm{a}}$ & -19.38 & \\
\hline N. Hemisphere & $-0.39^{b}$ & -16.72 & \\
\hline S. Hemisphere & $-1.1^{\mathrm{b}}$ & -2.66 & 2.93 \\
\hline Europe & $-0.28^{c}$ & -2.65 & 0.74 \\
\hline N. America & $-0.47^{c}$ & -2.55 & 1.20 \\
\hline E. Asia & $-0.44^{\mathrm{c}}$ & -4.40 & 1.94 \\
\hline S. Asia & $-0.88^{c}$ & -3.78 & 3.33 \\
\hline NH minus 4 regions & $-0.39^{b}$ & -3.34 & 1.30 \\
\hline \multicolumn{4}{|l|}{ Aviation emissions } \\
\hline Global & $-2.6^{a}$ & -0.83 & \\
\hline Global & $-2.5^{\mathrm{d}}$ & -0.83 & \\
\hline Global & $-2.3^{\mathrm{e}}$ & -0.83 & 1.91 \\
\hline $\begin{array}{l}\text { Various } 10^{\circ} \times 10^{\circ} \\
\text { model grid-boxes }\end{array}$ & -1.9 to $-15^{\mathrm{f}}$ & & \\
\hline
\end{tabular}

90 Table 1: Sensitivity of changes in the global methane burden $\left(\Delta \mathrm{CH}_{4}\right.$; units $\left.\mathbf{T g}\left(\mathrm{CH}_{4}\right)\right)$ to changes in NOx emissions $\left(\Delta \mathrm{E}_{\mathrm{NOx}}\right.$; units $\left.\mathrm{Tg}\left(\mathrm{NO}_{2}\right) \mathrm{yr}^{-1}\right)$ from several modelling studies, calculated for a variety of surface and aviation emissions from different regions. Also shown are COVID-19 lockdown impacts on NOx emissions ( $\left.\mathrm{Tg}\left(\mathrm{NO}_{2}\right) \mathrm{yr}^{-1}\right)$ between 2019 and 2020 from Lamboll et al. (2021) for regions and global aviation, and the corresponding contributions to the change in global methane burden ( $\mathrm{Tg}\left(\mathrm{CH}_{4}\right)$; values only given for contributions used in Section 4). References for the sensitivity values: (a) Wild et al. (2001); (b) Derwent et al. (2001); (c) Fry et al. (2012); (d) Stevenson et al. (2004); (e) Lee et al. (2021); and (f) Stevenson and Derwent (2009). 


\section{COVID-19 lockdown impacts on NOx emissions}

Lamboll et al. (2021) compiled estimates of the impact of COVID-19 lockdowns on global anthropogenic NOx emissions, as monthly mean time series, with spatial resolution $0.5^{\circ}$ latitude by $0.5^{\circ}$ longitude. We use these data to calculate the difference in surface NOx emissions between 2019 (pre-lockdown) and 2020 for the four HTAP regions, as well as for the Northern and

100 Southern Hemispheres. The annual reduction in global surface NOx emissions from 2019 to 2020 was about $19.38 \mathrm{Tg}\left(\mathrm{NO}_{2}\right)$, or 15\%. Lamboll et al. (2021) also compiled data on aviation emissions, estimating a global reduction of about $0.83 \mathrm{Tg}\left(\mathrm{NO}_{2}\right)$, or $25 \%$. Regional changes in NOx emissions are summarised in Table 1.

\section{Impacts of reduced NOx emissions on global methane}

To calculate an approximate impact of the NOx emission reductions on global methane, we simply multiply the

105 regional/aviation sensitivities and emissions changes and sum over the globe. Table 1 shows calculated regional and aviation components of the methane change. We calculate a total methane burden change of $13.36 \mathrm{Tg}\left(\mathrm{CH}_{4}\right)$, comprising $11.44 \mathrm{Tg}\left(\mathrm{CH}_{4}\right)$ from surface NOx changes, with a further $1.92 \mathrm{Tg}\left(\mathrm{CH}_{4}\right)$ from aircraft. The more sensitive regions (South Asia, the Southern Hemisphere) and aviation make proportionally larger contributions to the total methane change. We convert the overall change in global methane burden (Tg) to a change in tropospheric mole fraction (ppb) using the total atmosphere mass of $5.113 \times 10^{9}$

$110 \mathrm{Tg}$ and a fill factor of 0.973 for conversion of a total atmosphere abundance to a tropospheric abundance (Prather et al., 2012). This yields a global mean increase in tropospheric methane mole fraction of $4.9 \mathrm{ppb}$ associated with the NOx reductions. Since the troposphere is well mixed, this is also the change at the surface.

\section{Discussion and Conclusions}

This model-derived estimate of the extra methane expected due to the reductions in NOx emissions exactly matches the

115 observed extra growth in methane seen during lockdown from 2019 to 2020 (4.9 ppb), suggesting that the NOx changes can account for all or most of the observed methane changes.

Refinements to this simple estimate will need to account for several additional complications. The NOx emission changes have temporal structure (Lamboll et al., 2021), as do the sensitivities of methane to NOx (e.g., Stevenson et al., 2004), and these will interact. In addition, we have ignored any spatial variations in aircraft emissions, but Stevenson and Derwent (2009) found that NOx emissions into cleaner environments had larger effects; there are also likely spatial variations within the large regions we have used for the surface NOx emissions. Detailed modelling of the lockdown period is starting to explore these effects (Weber et al., 2020; Miyazaki et al., 2021). There is also spatio-temporal structure in the observed methane changes that will yield further information. There are undoubtedly several other factors, in addition to changes in NOx, that influenced methane during 2020. Nevertheless, it seems likely that the dramatic reductions in NOx emissions brought about by the COVID-19 lockdowns can explain a large component of the surge in methane growth rate seen since early 2020. 


\section{Author contributions}

DSS wrote the text and performed the main analysis. OW and WJC performed additional analysis and commented on the text. RGD commented on the text.

\section{Competing interests}

130 The authors declare that they have no conflict of interest.

\section{References}

Allen, M. R., Shine, K. P., Fuglestvedt, J. S., Millar, R. J., Cain, M., Frame, D. J., and Macey, A.H.: A solution to the misrepresentations of $\mathrm{CO}_{2}$-equivalent emissions of short-lived climate pollutants under ambitious mitigation. npj Clim. Atmos. Sci. 1, 16, https://doi.org/10.1038/s41612-018-0026-8, 2018.

135 Bauwens, M., Compernolle, S., Stavrakou, T., Müller, J.-F., van Gent, J., Eskes, H., et al.: Impact of coronavirus outbreak on $\mathrm{NO}_{2}$ pollution assessed using TROPOMI and OMI observations. Geophys. Res. Lett., 47, e2020GL087978, https://doi.org/10.1029/2020GL087978, 2020.

Cain, M., Lynch, J., Allen, M.R. et al.: Improved calculation of warming-equivalent emissions for short-lived climate pollutants. npj Clim. Atmos. Sci. 2, 29, https://doi.org/10.1038/s41612-019-0086-4, 2019.

140 Derwent, R.G., Collins, W.J., Johnson, C.E., and Stevenson, D.S.: Transient Behaviour of Tropospheric Ozone Precursors in a Global 3-D CTM and Their Indirect Greenhouse Effects, Climatic Change 49, 463-487, https://doi.org/10.1023/A:1010648913655, 2001.

Dlugokencky, E.: NOAA/GML Trends in Atmospheric Methane, https://gml.noaa.gov/ccgg/trends_ch4/, accessed 25/06/2021, 2021.

145 Etminan, M., G. Myhre, E. J. Highwood, and K. P. Shine: Radiative forcing of carbon dioxide, methane, and nitrous oxide: A significant revision of the methane radiative forcing, Geophys. Res. Lett., 43, 12,614-12,623, doi:10.1002/2016GL071930, 2016.

Fry, M. M., et al.: The influence of ozone precursor emissions from four world regions on tropospheric composition and radiative climate forcing, J. Geophys. Res., 117, D07306, doi:10.1029/2011JD017134, 2012.

150 Holmes, C. D.: Methane feedback on atmospheric chemistry: Methods, models, and mechanisms. Journal of Advances in Modeling Earth Systems, 10, 1087- 1099. https://doi.org/10.1002/2017MS001196, 2018.

Lamboll, R. D., Jones, C. D., Skeie, R. B., Fiedler, S., Samset, B. H., Gillett, N. P., Rogelj, J., and Forster, P. M.: Modifying emissions scenario projections to account for the effects of COVID-19: protocol for CovidMIP, Geosci. Model Dev., 14, 36833695, https://doi.org/10.5194/gmd-14-3683-2021, 2021. 
Lee, D.S., D.W. Fahey, A. Skowron, M.R. Allen, U. Burkhardt, Q. Chen, S.J. Doherty, S. Freeman, P.M. Forster, J. Fuglestvedt, A. Gettelman, R.R. De León, L.L. Lim, M.T. Lund, R.J. Millar, B. Owen, J.E. Penner, G. Pitari, M.J. Prather, R. Sausen, and L.J. Wilcox: The contribution of global aviation to anthropogenic climate forcing for 2000 to 2018, Atmospheric Environment, Volume 244, 117834, https://doi.org/10.1016/j.atmosenv.2020.117834, 2021.

Miyazaki, K., K. Bowman, T. Sekiya, M. Takigawa, J. L. Neu, K. Sudo, G. Osterman, and H. Eskes: Global tropospheric ozone responses to reduced NOx emissions linked to the COVID-19 worldwide lockdowns, Science Advances, 7, 24, eabf7460 DOI:10.1126/sciadv.abf7460, 2021.

Myhre, G., D. Shindell, F.-M. Bréon, W. Collins, J. Fuglestvedt, J. Huang, D. Koch, J.-F. Lamarque, D. Lee, B. Mendoza, T. Nakajima, A. Robock, G. Stephens, T. Takemura and H. Zhang: Anthropogenic and Natural Radiative Forcing. In: Climate Change 2013: The Physical Science Basis. Contribution of Working Group I to the Fifth Assessment Report of the Intergovernmental Panel on Climate Change [Stocker, T.F., D. Qin, G.-K. Plattner, M. Tignor, S.K. Allen, J. Boschung, A. Nauels, Y. Xia, V. Bex and P.M. Midgley (eds.)]. Cambridge University Press, Cambridge, United Kingdom and New York, NY, USA, 2013.

Prather, M.J.: Lifetimes and Eigenstates in Atmospheric Chemistry, Geophys. Res. Lett., 21, 801-804, 1994.

Prather, M. J., Holmes, C. D., and Hsu, J.: Reactive greenhouse gas scenarios: Systematic exploration of uncertainties and the role of atmospheric chemistry, Geophys. Res. Lett., 39, L09803, doi:10.1029/2012GL051440, 2012.

Stevenson, D.S. and R.G. Derwent: How does the location of aircraft nitrogen oxide emissions affect their climate impact? Geophys. Res. Lett., 36, L17810, doi:10.1029/2009GL039422, 2009.

Stevenson, D. S., Doherty, R. M., Sanderson, M. G., Collins, W. J., Johnson, C. E., and Derwent, R. G.: Radiative forcing from aircraft NOx emissions: Mechanisms and seasonal dependence, J. Geophys. Res., 109, D17307, doi:10.1029/2004JD004759, 2004.

Stevenson, D. S., Young, P. J., Naik, V., Lamarque, J.-F., Shindell, D. T., Voulgarakis, A., Skeie, R. B., Dalsoren, S. B., Myhre, G., Berntsen, T. K., Folberth, G. A., Rumbold, S. T., Collins, W. J., MacKenzie, I. A., Doherty, R. M., Zeng, G., van Noije, T. P. C., Strunk, A., Bergmann, D., Cameron-Smith, P., Plummer, D. A., Strode, S. A., Horowitz, L., Lee, Y. H., Szopa, S., Sudo, K., Nagashima, T., Josse, B., Cionni, I., Righi, M., Eyring, V., Conley, A., Bowman, K. W., Wild, O., and Archibald,

180 A.: Tropospheric ozone changes, radiative forcing and attribution to emissions in the Atmospheric Chemistry and Climate Model Intercomparison Project (ACCMIP), Atmos. Chem. Phys., 13, 3063-3085, https://doi.org/10.5194/acp-13-3063-2013, 2013.

Turner, A.J., I. Fung, V. Naik, L. W. Horowitz, R. C. Cohen: Modulation of hydroxyl variability by ENSO in the absence of external forcing, Proceedings of the National Academy of Sciences, 115 (36) 8931-8936; DOI: 10.1073/pnas.1807532115, 1852018.

Vaughan, A.: A mysterious rise in methane levels is sparking global warming fears, New Scientist, https://www.newscientist.com/article/mg25033350-700-a-mysterious-rise-in-methane-levels-is-sparking-global-warmingfears/ [accessed $14^{\text {th }}$ July 2021], 2021. 
https://doi.org/10.5194/acp-2021-604

Preprint. Discussion started: 3 August 2021

(c) Author(s) 2021. CC BY 4.0 License.

(c) (1)

Venter, Z.S., K. Aunan, S. Chowdhury, J. Lelieveld: COVID-19 lockdowns cause global air pollution declines, Proceedings

of the National Academy of Sciences, 117 (32) 18984-18990; DOI: 10.1073/pnas.2006853117, 2020.

Weber, J., Shin, Y. M., Staunton Sykes, J., Archer-Nicholls, S., Abraham, N. L., \& Archibald, A. T.: Minimal climate impacts from short-lived climate forcers following emission reductions related to the COVID-19 pandemic. Geophysical Research Letters, 47, e2020GL090326. https://doi.org/10.1029/2020GL090326, 2020.

Wild, O., Prather, M.J., and Akimoto, H.: Indirect long-term global radiative cooling from NOx emissions, Geophys. Res.

195 Lett., 28, 1719-1722, 2001.

World Meteorological Organization: State of the Global Climate 2020 (WMO-No. 1264), https://public.wmo.int/en/ourmandate/climate/wmo-statement-state-of-global-climate, accessed 14-07-21, 2021.

Zhao, Y., Saunois, M., Bousquet, P., Lin, X., Berchet, A., Hegglin, M. I., Canadell, J. G., Jackson, R. B., Deushi, M., Jöckel, P., Kinnison, D., Kirner, O., Strode, S., Tilmes, S., Dlugokencky, E. J., and Zheng, B.: On the role of trend and variability in 200 the hydroxyl radical (OH) in the global methane budget, Atmos. Chem. Phys., 20, 13011-13022, https://doi.org/10.5194/acp20-13011-2020, 2020. 